\title{
Editorial
}

\section{Educação Interprofissional e a participação da Terapia Ocupacional nos Projetos de Educação Permanente em Saúde}

\section{Interprofessional education and the participation of Occupational Therapy in the process of Permanent Education in Health}

O desenvolvimento do Sistema Único de Saúde (SUS) em nosso país provocou considerável expansão do setor com consequente aumento dos empregos na área da saúde. Dados mostram que em 1980 existiam no país 573.629 empregos em saúde, já em 200 esse número atingiu cerca de 2 milhões e 500 mil empregos. O setor público é responsável por mais da metade (56\%) desse contingente, sendo que $69 \%$ desse total se refere á esfera municipal.

Em 2009 estimava-se que o SUS dispunha de cerca de 341 médicos, e mais de 178 mil enfermeiros, 137 mil psicólogos e 230 mil agentes comunitários de saúde. Em relação aos Fisioterapeutas e Terapeutas Ocupacionais estimava-se que em 2005 existiam 32.266 profissionais.

Nesse contexto, se torna fundamental a definição de metas e o desenvolvimento de práticas, no âmbito da graduação e dos programas de educação permanente, voltados para a formação para o SUS, daí a importância, especialmente para os docentes dos cursos de terapia ocupacional, do conhecimento e fortalecimento da participação nas iniciativas desenvolvidas no âmbito da Política Nacional de Educação Permanente em Saúde (PNEPS).

Essa política é coordenada pelo Ministério da Saúde por meio da Secretaria de Gestão do Trabalho e da Educação em Saúde (SGTES) e visa desenvolver e fortalecer a formação, o desenvolvimento profissional e o trabalho no setor saúde, tanto na formação técnica quanto na de graduação e pós graduação. Desse conjunto destacamos os programas nos quais a inclusão e participação de terapia ocupacional já começa a ganhar visibilidade e cria um campo de práticas e produção de conhecimento que deve ser, cada vez mais, valorizado pois propiciam inovações conceituais e práticas e a vivência da prática da educação interprofissional (BRASIL, 2011).

A inclusão dos cursos, docentes, alunos e profissionais da terapia ocupacional no Pró-Saúde, Pet-Saúde e PetSaúde Mental e em diversos programas de Residência Multiprofissional, embora ainda pequena, já propicia um amplo campo de reflexão e visibilidade, sobre as práticas desenvolvidas em Terapia Ocupacional no contexto do trabalho em equipe, em diversos contextos da saúde e, especialmente, na atenção básica.

Dessa forma, convidamos os pesquisadores que integram esses projetos a produzirem artigos originais de pesquisa, reflexões e debates e relatos de experiências que contribuam para a ampliação da divulgação e visibilidade das iniciativas e que, especialmente, tragam contribuições para o importante debate em torno do tema do ensino interprofissional e do trabalho em equipe.

\section{REFERÊNCIA}

BRASIL. Gestão do trabalho e da educação em saúde (SGETS) [citado em 2011]. Disponível em: http://portal.saude.gov.br/portal/ saude/gestor/area.cfm?id_area=382. 